\title{
IGF2 increases de novo steroidogenesis in prostate cancer cells
}

\author{
Amy A Lubik ${ }^{1,2}$, Jennifer H Gunter ${ }^{1}$, Brett G Hollier ${ }^{1}$, Susan Ettinger ${ }^{2}$, Ladan Fazli ${ }^{2}$, \\ Nataly Stylianou', Stephen C Hendy ${ }^{2}$, Hans H Adomat ${ }^{2}$, Martin E Gleave ${ }^{2}$, \\ Michael Pollak ${ }^{3}$, Adrian Herington ${ }^{1}$ and Colleen C Nelson ${ }^{1,2}$ \\ ${ }^{1}$ Institute of Health and Biomedical Innovation, Australian Prostate Cancer Research Centre - Queensland, Princess \\ Alexandra Hospital, Queensland University of Technology, Level 1, Building 1, 199 Ipswich Road, Brisbane, \\ Queensland 4102, Australia \\ ${ }^{2}$ Vancouver Prostate Centre, University of British Columbia, Vancouver, British Columbia, Canada \\ ${ }^{3}$ Departments of Medicine and Oncology, Jewish General Hospital, McGill University, Montreal, Quebec, Canada
}

Correspondence should be addressed to C C Nelson

Email

colleen.nelson@qut.edu.au

\begin{abstract}
IGF2 is a mitogenic foetal growth factor commonly over-expressed in cancers, including prostate cancer (PC). We recently demonstrated that insulin can activate de novo steroidogenesis in PC cells, a major pathway for reactivation of androgen pathways and PC progression. IGF2 can activate the IGF1 receptor (IGF1R) or insulin receptor (INSR) or hybrids of these two receptors. We therefore hypothesized that IGF2 may contribute to PC progression via de novo steroidogenesis. IGF2 mRNA but not IGF2 receptor mRNA expression was increased in patient samples during progression to castrate-resistant $P C$ as was immunoreactivity to INSR and IGF1R antibodies. Treatment of androgen receptor (AR)-positive PC cell lines LNCaP and 22RV1 with IGF2 for $48 \mathrm{~h}$ resulted in increased expression of steroidogenic enzyme mRNA and protein, including steroid acute regulatory protein (StAR), cytochrome p450 family member (CYP)17A1, aldo-keto reductase family member (AKR)1C3 and hydroxysteroid dehydrogenase (HSD)17B3. IGF2 treatment resulted in increased steady state steroid levels and increased de novo steroidogenesis resulting in $A R$ activation as demonstrated by PSA mRNA induction. Inhibition of the IGF1R/INSR signalling axis attenuated the effects of IGF2 on steroid hormone synthesis. We present a potential mechanism for prostatic IGF2 contributing to PC progression by inducing steroidogenesis and that IGF2 signalling and related pathways present attractive targets for PC therapy.
\end{abstract}
Key Words
- Castrate-resistant prostate cancer
- IGF2
- steroidogenesis
- androgen receptor

Endocrine-Related Cancer (2013) 20, 173-186

\section{Introduction}

Insulin-like growth factors (IGFs) play an integral role in the progression of many cancers (Pollak 2008a,b), regulating proliferation and transformation, as well as inhibiting apoptosis (Pollak 2008a). Both the related growth factors insulin and IGF1 have been implicated in prostate cancer (PC) progression (Pollak 2008a, Lubik et al. 2011); however, the role of IGF2 is less well explored. IGF2 expression is elevated in ovarian, colorectal and breast cancer associated with poor prognosis (Cardillo et al. 2003, Sayer et al. 2005, Kalla Singh et al. 2007, Pollak 2008a, Huang et al. 2010) and increased cell motility (Diaz et al. 2007). Dysregulated expression of IGF2 in PC tumours and in surrounding prostate and stromal tissue occurs partially through loss of imprinting (Van Roozendaal et al. 1998,

Published by Bioscientifica Ltd. 
Cui et al. 2003, Poirier et al. 2003, Bhusari et al. 2011, Wang et al. 2011) and correlates with tumour vs benign hyperplasia (Paradowska et al. 2009); however, tumour IGF2 expression levels are not reflected in serum (Rowlands et al. 2009, 2012). IGF2 can signal through the IGF1 receptor (IGF1R) or via the insulin receptor (INSR) to elicit insulin-like signalling (Cardillo et al. 2003, Pandini et al. 2004). In parallel to increased IGF2, increasing expression of these receptors has been demonstrated in PC progression (Cox et al. 2009).

Androgen deprivation therapy (ADT), which removes testicular androgens necessary for survival of prostate cells, is the standard treatment for advanced PC (So et al. 2005). Local tumour production and/or retention of steroids has been shown to differ significantly to levels in the circulation and contribute to PC progression (So et al. 2005, Stanbrough et al. 2006), so despite castrate levels of androgens in men undergoing ADT, it has been shown by our group and others that the local prostatic production of steroids (and conversion of adrenal precursors) may be instrumental in driving PC progression towards the terminal castrate-resistant PC (CRPC) (Locke et al. 2008). The clinical success of the CYP17A1 inhibitor, abiraterone (Attard et al. 2008, 2011), highlights the importance of this pathway in PC progression. At this stage of disease, circulating androgen levels are low, while the prostate tissue levels are high enough to reactivate the androgen receptor (AR), which may itself harbour mutations that give rise to constitutively active truncated receptors or increase AR sensitivity to low androgen and drive progression (Stanbrough et al. 2006, Locke et al. 2008). We recently reported that insulin, which rises in response to ADT, can drive expression of steroidogenesis enzymes in PC cells, increase intracellular androgens and increase expression of PSA (Lubik et al. 2011). Given the similarities in signalling between insulin and IGF2 (Pandini et al. 2004), we hypothesized that the increased IGF2 in the tumour microenvironment may accelerate prostatic de novo steroidogenesis. IGF2 has been shown to initiate steroidogenesis in thecal (Spicer \& Aad 2007) and adrenocortical cells (Fottner et al. 1998). In this study, we observed increased IGF2 transcript in clinical tumour samples, which correlated with progression to castrate resistance in addition to increased expression of the receptors that facilitate IGF2 signalling: IGF1R and INSR. Our results demonstrate that IGF2 may accelerate PC progression through up-regulation of steroidogenesis enzymes and enhanced steroid production in PC cell lines. Levels of steroidogenic enzyme mRNA and protein in LNCaP and 22RV1 cells are increased after IGF2 treatment and result in increased DHT secretion. Increased de novo steroidogenesis in $\mathrm{LNCaP}$ and $\mathrm{VCaP}$ cells was measured using radiolabelled substrate, which resulted in androgen-mediated reactivation of AR and up-regulated expression of PSA.

\section{Materials and methods}

\section{Laser capture microdissection and microarray analysis}

Microarray analysis of mRNA was performed using samples of patient tissue after radical prostatectomy grouped into the following categories: 14 primary PCs from patients undergoing surgery with no therapy before surgery, 12 primary prostatectomy samples from patients receiving 1-3 months of neoadjuvant hormone therapy (NHT) before surgery, five primary PCs after 5-6 months of NHT before surgery, four primary PCs after 8-9 months of NHT before surgery and three hormone refractory PCs before surgery. Patients were further grouped according to the following risk factors: high (PSA $>20$, Gleason $>7$, clinical stage T3-T4), intermediate (PSA 10-20, Gleason 7, clinical stage T2) and low (PSA $<10$, Gleason $<7$, clinical stage 1 ).

The array preparation was performed as described previously (Chi et al. 2005). Tissues were flash frozen in OCT Compound (Tissue-Tek, VWR, Batavia, IL, USA) and frozen sections $(8 \mu \mathrm{m})$ were cut and mounted on laser capture microdissection (LCM) slides (P.A.L.M. Microlaser Technologies, Bernried, Germany), sections were briefly thawed and fixed with $95 \%$ ethanol at $-25^{\circ} \mathrm{C}$. Haematoxylin staining was followed by washes in diethyl pyrocarbonate (DEPC) water and then dehydration in $100 \%$ ethanol and LCM was performed on cancer cells using the photoactivation localisation microscopy (PALM). Microlaser system. Total RNA was isolated (PicoPure RNA Isolation Kit, ARCTURUS, Carlsbad, CA, USA) and amplified using the RiboAmp HS RNA Amplification kit (ARCTURUS), labelled with Cy5 using the AminoAllyl Message Amp IIa RNA Amplification Kit (Ambion, Streetsville, ON, Canada) and fragmented with RNA Fragmentation Reagents (Ambion) before hybridization. Custom-designed microarrays of 34580 (70-mer) human oligos representing 24650 genes and 37123 gene transcripts (Human Operon V3.0, Operon Technologies, Huntsville, AL, USA) were supplied by the Microarray Facility of the Vancouver Prostate Centre. Scanned arrays were visualized using ImaGene 8.0 Software (BioDiscovery, San Diego, CA, USA). Feature data were subjected to background correction, print-tip-lowess within-array normalization and $\mathrm{G}$ quantile between-array normalization

Published by Bioscientifica Ltd. 
(Limma, R/Bioconductor Software, Seattle, WA, USA). Significant differences between treatment groups were assessed using linear regression and BenjaminiHochberg multiple test correction to estimate the false discovery rate.

\section{Immunohistochemistry}

Immunohistochemical (IHC) staining was conducted on sequential sections of the Gleason-graded tissue microarray (TMA) on patients from a similar cohort, also receiving NHT therapy before radical prostatectomy. Samples were probed using INSR receptor, $\beta$-subunit, rabbit immunoaffinity-purified IgG (Upstate Cell Signaling Solutions, Lake Placid, NY, USA) and IGF1R $\beta$ rabbit polyclonal antibody (Santa Cruz Biotechnology, Inc.) with enzyme-labelled biotin streptavidin system and solventresistant DAB Map kit. Nonspecific reactivity was assessed by omission of the primary antibody. The specificity of staining for INSR was confirmed using placenta as a positive control. The slide was scanned with BLISS system (Bacus Lab, North Lombard, IL, USA) and IHC score staining intensity was evaluated by an independent pathologist. The biomarkers were scored using a four-point scale scoring system by a pathologist. Descriptively, 0 represents no staining by any tumour cells, 1 represents a faint or focal, 2 represents a stain of moderate intensity in a convincing number of cells and 3 represents intense staining by a sufficient number of cells expressing this antigen.

\section{Cells}

LNCaP and 22RV1 cells were purchased from American Type Culture Collection (ATCC, Manassas, VA, USA) and routine array analyses performed in our laboratory confirm expected gene profiles. Cells were maintained in phenol red-free RPMI 1640 (Invitrogen), 5\% (v/v) foetal bovine serum (FBS; Invitrogen). VCaP cells were maintained in DMEM media (Hyclone, Hudson, NH, USA), $5 \%$ FBS. Cells were plated overnight in respective media containing 5\% FBS before media were changed to media with 5\% charcoal-stripped serum (CSS; Hyclone) for $24 \mathrm{~h}$ before 24 -h starvation in serum-free media. Following optimization of concentration and duration, cells were treated with $85 \mathrm{ng} / \mathrm{ml}$ IGF2 (Novozymes, Thebarton, SA, Australia) in $0.2 \%$ BSA in SFM or $0.2 \%$ BSA (w/v) alone for 48-72 h. IGF2 was refreshed at 24-h intervals as necessary. Serum levels of IGF2 range from 200 to $600 \mathrm{ng} / \mathrm{ml}$ in men $\sim 65$ years of age (with and without PC; Harman et al. 2000).

\section{Receptor inhibitor treatment}

LNCaP and 22RV1 cells were grown in six-well plates for $24 \mathrm{~h}$ in FBS-supplemented media before incubation in 5\% CSS media for $24 \mathrm{~h}$ and further $24-\mathrm{h}$ incubation in serumfree media. For AR inhibition, cells were incubated for $2 \mathrm{~h}$ with $25 \mu \mathrm{M}$ bicalutamide and then for $24 \mathrm{~h}$ with $85 \mathrm{ng} / \mathrm{ml}$ IGF2 or $10 \mathrm{nM}$ dihydrotestosterone (DHT). For inhibition of receptor activation by IGF2, cells were incubated with either $5 \mu \mathrm{M}$ BMS-754807 (Bristol-Myers Squibb, Montreal, Quebec, Canada) pan-INSR/IGF1R inhibitor or $12.5 \mu \mathrm{g} / \mathrm{ml}$ of specific IGF1R inhibitor, CP-751,871 (Pfizer) for $2 \mathrm{~h}$ before addition of IGF2. To determine the difference between IGF2 and $10 \mathrm{nM}$ insulin-induced steroid synthesis, $100 \mathrm{nM}$ INSR-specific inhibitor, S661 (Novo Nordisk), was employed. Ketoconazole, $10 \mu \mathrm{M}$ (Sigma), demonstrated IGF2, or insulin-induced steroidogenesis could be suppressed with this steroidogenic inhibitor. All treatments were normalized to vehicle control. LNCaP cells were then treated as earlier with ${ }^{14} \mathrm{C}$-acetate and IGF2 before de novo steroidogenesis analysis. 22RV1 cells, not treated with ${ }^{14} \mathrm{C}$-acetate, were analysed using DHT ELISA. All inhibitors were used with kind permission.

\section{Quantitative real-time PCR}

Quantitative real-time PCR (QRT-PCR) was carried out using standard methods. Briefly, RNA was extracted from cell lines using Tri-Reagent (Applied Biosystems), before RT with Superscript III RT (Invitrogen). QRT-PCR was performed using SYBR Green detection on 7900HT Fast Real Time PCR System (Applied Biosystems). Primers used are listed in Table 1. Gene expression was normalized to the housekeeping gene and then expressed relative to vehicle control at the same time point. Data were analysed using SDS 2.3 Software (Life Technologies Australia Pty Ltd, Mulgrave, Victoria 3170, Australia) by means of the $2^{-\triangle \Delta C T}$ method (Livak \& Schmittgen 2001). Experiments were repeated a minimum of five times.

\section{Western blotting}

Protein extraction and western blotting were carried out as described previously (Lubik et al. 2011). Briefly, cells were lysed in radioimmunoprecipitation assay buffer, proteins separated by SDS-PAGE and transferred to PVDF-FL membrane (Millipore, North Ryde, NSW, Australia). Antibodies were added in a 1:1 solution of Li-Cor blocking buffer (Li-Cor Biosciences, Lincoln, NE, USA) and 0.1\% Tween 20-PBS and incubated overnight at $4{ }^{\circ} \mathrm{C}$, before

Published by Bioscientifica Ltd. 
Table 1 Primers used for QRT-PCR.

\begin{tabular}{|c|c|c|}
\hline Gene & Forward primer $\left(5^{\prime}-3^{\prime}\right)$ & Reverse primer $\left(5^{\prime}-3^{\prime}\right)$ \\
\hline$t A R$ & gcccatggagaggctctatg & ttccactcccccattgctt \\
\hline CYP11A1 & tcgtcagt & ggagcccgccttcttga \\
\hline CYP17A1 & gggcggcctcaaatgg & $\begin{array}{l}\text { cagcgaaggcgaaggcga- } \\
\text { taccctta }\end{array}$ \\
\hline$H S D$ & cggg & ttttccagaggctcttcttcgt \\
\hline$A K R 1 C 3$ & $\operatorname{tggg}$ & tttgacaccccaatggacttg \\
\hline HSD17B3 & aftgggcagtga & cgagtacgctttcccaattcc \\
\hline SRD5A1 & acgggcatcggtgcttaat & ccaacagtggcataggctttc \\
\hline RDH5 & gcccgccagcaatgc & cgcccaaagcctgagtca \\
\hline $\begin{array}{l}P S A \\
P P I>z^{a}\end{array}$ & agtgcgagaagcattcccaac & ccagcaagatcacgcttttgtt \\
\hline$R P L 32^{\mathrm{a}}$ & ccccttgtgaagcccaaga & gactggtgccggatgaactt \\
\hline
\end{tabular}

${ }^{\mathrm{a}}$ House-keeping gene.

application of secondary antibody. Blots were visualized using the Li-Cor Odyssey Imager. Antibodies used were as described previously (Lubik et al. 2011). Experiments were repeated a minimum of three times.

\section{Steroid analysis}

LNCaP cells were grown in $15 \mathrm{~cm}$ plates and treated with either $85 \mathrm{ng} / \mathrm{ml}$ IGF2 in $0.5 \%$ BSA or $0.5 \%$ BSA in SFM for $48 \mathrm{~h}$. Two plates of treated cells were washed with PBS and combined to give a single sample. Steroids were extracted from the pellet with methyl-tert-butyl ether (MTBE)/ methanol/water extraction, which was dried down and resuspended in acetonitrile, sonicated, dried down and resuspended in 50\% methanol and then sonicated and spun to remove any particulates. Samples were derivatized in $0.2 \mathrm{M}$ hydroxylamine $\mathrm{HCl}$. Water equilibrated ethylacetate was used instead of MTBE/methanol/ water for extraction of secreted steroids from media samples. All samples were run on the Waters Acquity Liquid Chromatography system and the Waters Quattro Premier LC/MS/MS and analysed using BioLynx Software. Readings were normalized to cell pellet weight. Before extraction, d3T-deuterated testosterone standard $(0.015 \mathrm{ng} / \mathrm{ml}$ final concentration) was added.

\section{Radiolabelled analysis of de novo steroidogenesis in LNCaP and VCaP cells}

Cells were grown in six-well plates and treated as earlier. At the time of IGF2 treatment, $6 \mu \mathrm{Ci} / \mathrm{ml}{ }^{14} \mathrm{C}$-acetate (PerkinElmer, Woodbridge, ON, Canada) was added to each plate for $72 \mathrm{~h}$ after which time medium was analysed for steroid content. Equal volumes of medium and hexane:ethylacetate $(75: 25)$ were incubated at room temperature for $1 \mathrm{~h}$ and the organic phase was extracted twice. Samples were then dried and resuspended in $75 \mu \mathrm{l}$ $50 \%$ methanol. These samples were analysed on the Waters Alliance 2695 HPLC. Before extraction, d3Tdeuterated testosterone standard $(0.015 \mathrm{ng} / \mathrm{ml}$ final concentration) was added.

\section{Steroid analysis using DHT ELISA}

DHT secreted into the media by 22RV1 cells was evaluated using a DHT ELISA (BioCore Pty Ltd.) kit according to the manufacturer's instructions. Limits of detection of this kit were $6 \mathrm{pg} / \mathrm{ml}$, which is similar to that of our $\mathrm{LC} / \mathrm{MS} / \mathrm{MS}$ procedure.

\section{Statistical analysis}

Statistical analyses were performed using ANOVA on GraphPad Prism Software.

\section{Results}

\section{IGF2 mRNA expression in prostate tissue from men undergoing NHT}

We examined the levels of IGF2 mRNA expression in clinical tumour samples over the time of progression to castrate resistance (CRPC) in men undergoing NHT before radical prostatectomy. Prostatic tissue from patients undergoing radical prostatectomy after no NHT, 1- to 3-month NHT, 5- to 6-month NHT, 8- to 9-month NHT or having hormone refractory PCs, was examined by microarray analysis. Increased expression of IGF2 first occurred by 5-6 months. This reached statistical significance after 8-9 months and was maintained at CRPC (Fig. 1a). IGF2 receptor (IGF2R) mRNA levels remained constant (Fig. 1a), which suggests an altered ratio of free and bound IGF2, which may result in increased bioavailability of IGF2. IHC staining of NHT samples showed an increase in IGF1R and INSR protein immunoreactivity, both of which may be subject to activation by IGF2 (Fig. $1 \mathrm{~b}$ and c). INSR demonstrated homogenous cytoplasmic staining within tumour cells and discontinuous staining in the basal cell layer of benign glands. IGF1R protein expression was apparent in basal and luminal cells of the benign glands as well as cancer cells. Immunoreactivity of IGF1R was localized predominantly to the cell membrane, with approximately double the staining in CRPC samples; no cytoplasmic staining was observed in early series samples (0-5 months) compared with occasional cytoplasmic staining in CRPC samples.

Published by Bioscientifica Ltd. 


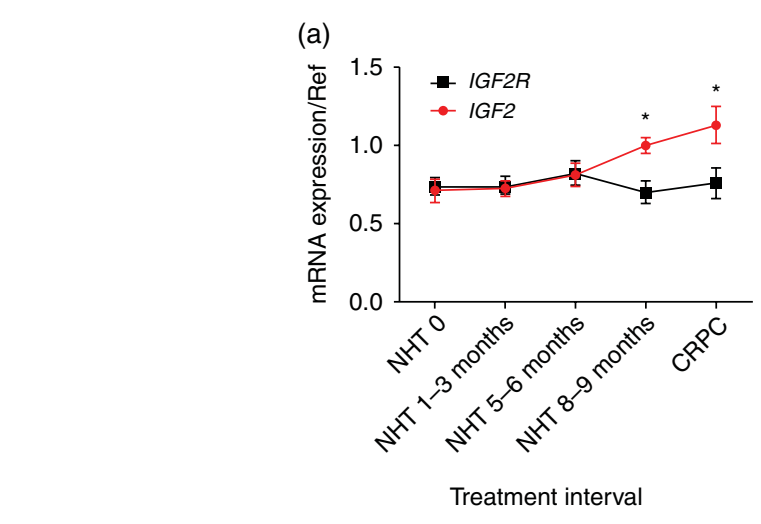

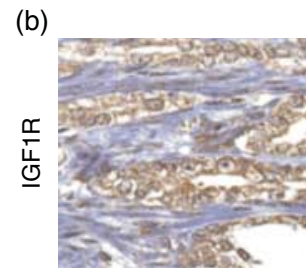

NHT 0

(c)

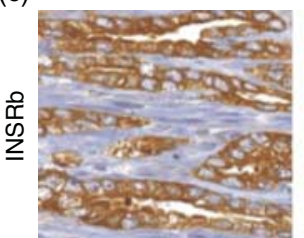

NHT 0

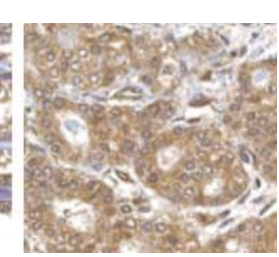

CRPC

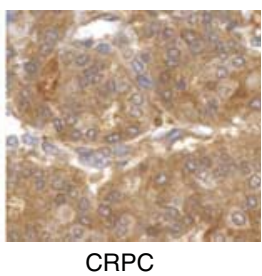

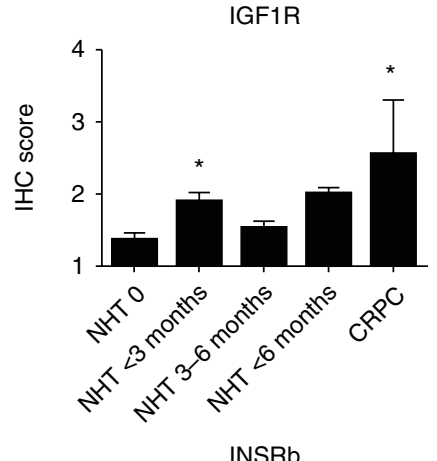

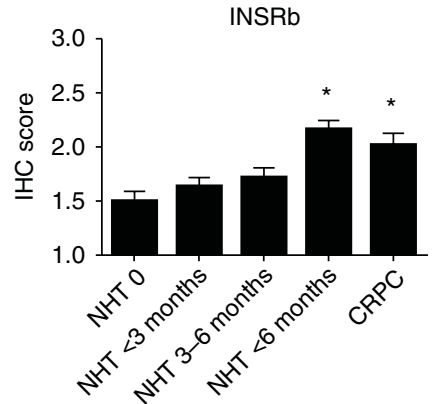

\section{Figure 1}

IGF2 and receptor expression in prostate cancer. Prostatic tissues included primary tumours from patients undergoing radical prostatectomy with no therapy before surgery (NHT 0), following 1-3 months of neoadjuvant hormone therapy (NHT), 5-6 months of NHT, 8-9 months of NHT and three castrate-resistant prostate cancers (CRPC). (a) IGF2 (red) and IGF2R (black)

\section{IGF2 increases expression of steroidogenesis enzymes}

Because IGF2 has been shown, in other tissues, to induce expression of enzymes in the steroidogenesis pathways, we investigated its potential to induce steroidogenesis in AR-positive prostate tumour cell lines, LNCaP and 22RV1. Working systematically through the steroidogenesis pathway (Fig. 2), we observed a statistically significant approximately twofold increase in mRNA levels of steroid acute regulatory protein $(S t A R), C Y P 17 A 1, S R D 5 A 1$ and retinol 11-cis dehydrogenase $R D H 5(P<0.05)$ in $\mathrm{LNCaP}$
mRNA levels from patient samples were compared between groups (mean + s.E.M.; ${ }^{*} P<0.05$ ). IHC staining of (b) IGF1R and (c) INSR from NHT-naïve tumour (left) and CRPC tumour (right) show increased staining at CRPC. Staining intensity was scored from 0 to 3 and graphed (mean + S.E.M.; ${ }^{*} P<0.05$ )

cells after $48 \mathrm{~h}$, as well as a 2 - and 1.5-fold increase in aldo-keto reductase family member $(A K R) 1 C 3(P=0.064)$ and $H S D 17 B 3$ respectively (Fig. 3a).

Parallel increases in protein expression of steroidogenesis enzymes were observed in LNCaP cells following IGF2 treatment (Fig. 3b). Expression of the cholesterol chaperone protein StAR was significantly increased approximately threefold, along with a twofold increase in levels of the rate-limiting enzyme, CYP17A1 as well as HSD17B3 (Fig. 3b). Levels of AKR1C3 and SRD5A proteins

Published by Bioscientifica Ltd. 


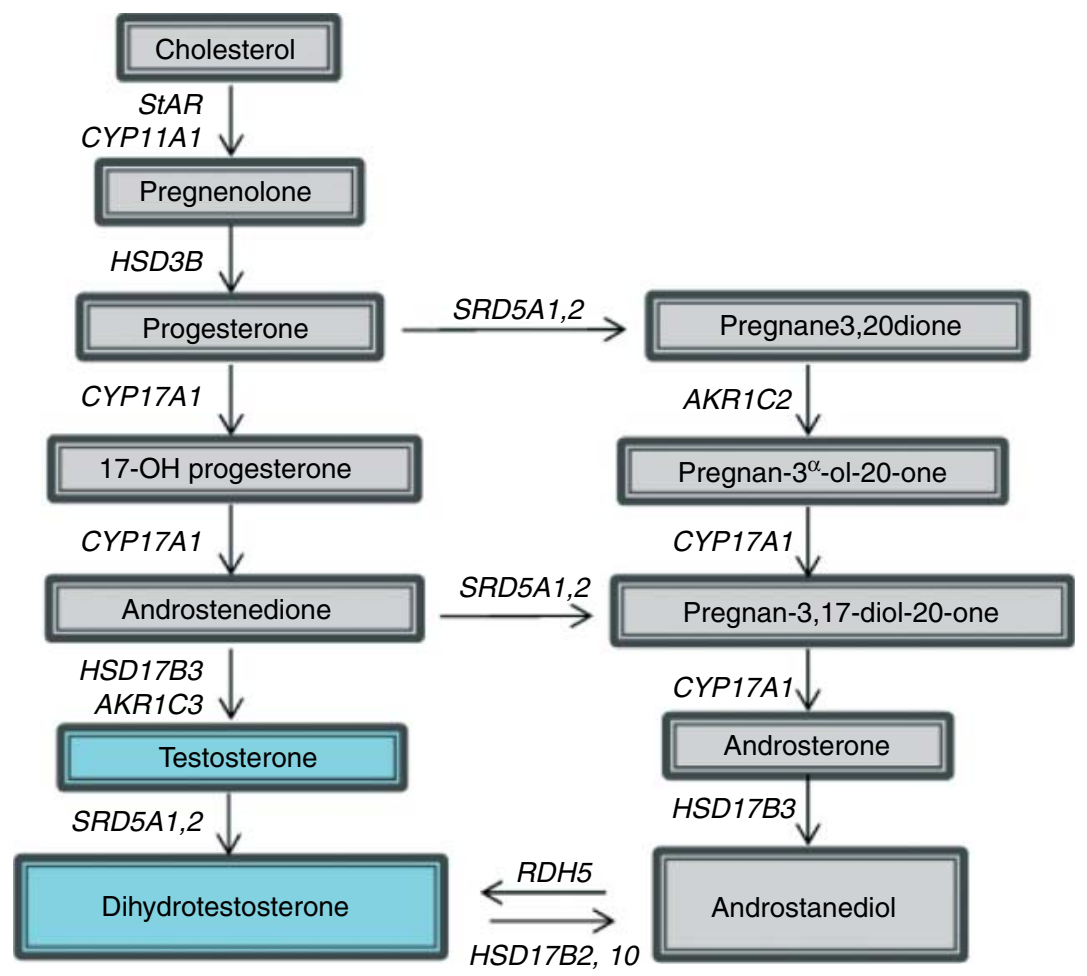

Figure 2

Steroidogenesis pathways indicating enzymes involved in both classical (left) and backdoor (right) pathways of DHT production.

increased, although did not reach statistical significance. In contrast to increased mRNA levels, protein levels of RDH5 were unchanged at $48 \mathrm{~h}$.

In comparison to LNCaPs, 22RV1 cells showed a similar pattern of mRNA induction for StAR (1.8-fold, $P>0.05$ ), CYP17A1 (2.9-fold), AKR1C3 (2.6-fold, $P>0.05$ ) and RDH5 (Fig. 3c). In contrast to LNCaPs, IGF2 induced an increase in CYP11A1 mRNA (1.5-fold), and HSD3B2 (twofold, $P<0.05$ ), but not in $H S D 17 B 3$ mRNA. Despite having similar magnitude changes in gene expression, much greater absolute levels of most steroidogenic enzymes were detected in 22RV1 cells.

Parallel changes in protein levels were observed in 22RV1 cells, as StAR increased fivefold, CYP11A1 and CYP17A1 increased approximately twofold each and HSD3B2 and AKR1C3 increased approximately twofold each $(P<0.05$; Fig. 3d). A small increase in HSD17B3 was also observed.

\section{IGF2 increases intracellular and secreted steroids}

HPLC on LNCaP cell pellets extracted with MTBE was used to investigate the differences in steroid content between
IGF2 and vehicle-treated cells. IGF2 treatment clearly increased intracellular steroid levels in LNCaP cells (Fig. 4a); a twofold increase in intracellular DHEA and $17 \mathrm{OH}$-progesterone $(P<0.05)$ and a tenfold increase in androsterone $(P<0.05)$, an intermediate in the backdoor steroid biogenesis pathway, were also observed. Pregnenolone and progesterone increased five- and threefold respectively $(P<0.05)$ and intracellular testosterone increased fourfold $(P<0.05)$ from $\sim 0.0131-0.053 \mathrm{ng} / \mathrm{g}$ cells with IGF2 treatment, which is consistent with our previous findings (Locke et al. 2008, Lubik et al. 2011). These concentrations would be sufficient to activate the $\mathrm{AR}$, as it has been shown that androgen concentrations of $\sim 2.92 \times 10^{-6} \mathrm{ng} / \mathrm{g}$ may activate AR in PC cell lines (Gregory et al. 2001). Interestingly, no change was observed in intracellular DHT.

By contrast, dramatic increases (approximately tenfold, $P<0.05)$ in secreted steroids were observed for testosterone, DHT and androsterone (Fig. 4b). Small increases in DHEA and 17OH-progesterone were detected, as well as five- and nine-fold increases in pregnenolone and progesterone respectively. Notably, higher levels of steroids at the beginning of the steroidogenesis pathway

Published by Bioscientifica Ltd 

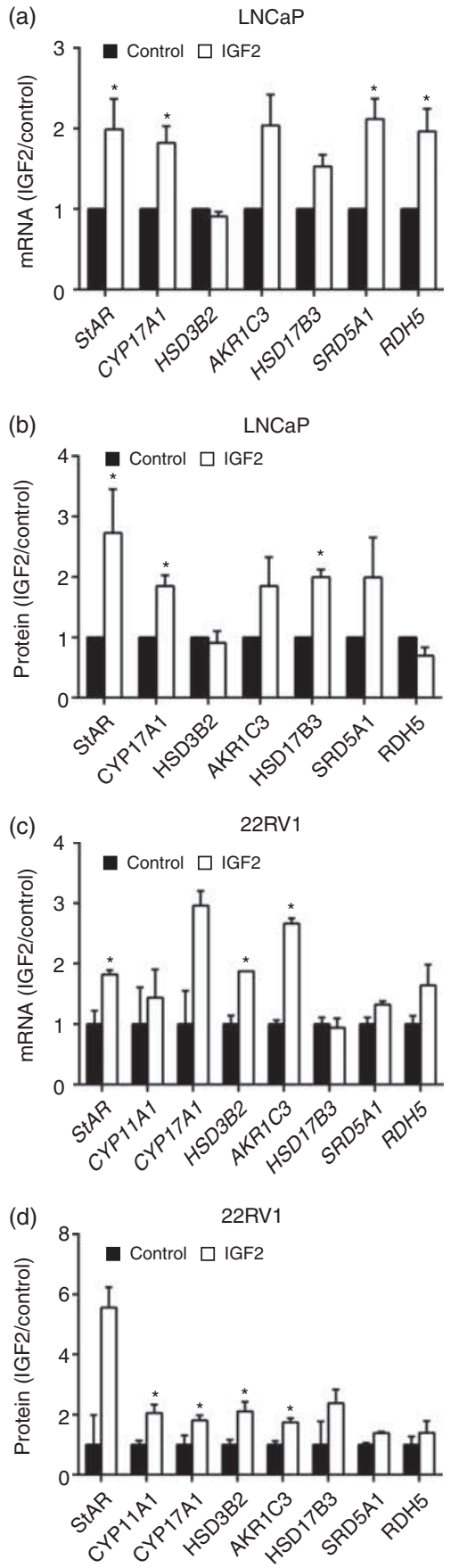

\section{Figure 3}

IGF2 up-regulates expression of steroidogenic enzyme mRNA and protein. (a) RNA from LNCaP cells treated with $85 \mathrm{ng} / \mathrm{ml}$ IGF2 for $48 \mathrm{~h}$ increased StAR, CYP17A1, SRD5A1 and RDH5 expression. Results analysed by $\triangle \Delta C T$ method normalized to RPL32 and then to vehicle-treated controls for the equivalent time point $(n=5)$. (b) Quantitated densitometry of western blot from LNCaP lysates treated for $48 \mathrm{~h}, 85 \mathrm{ng} / \mathrm{ml}$ IGF2 showed increased StAR, CYP17A1, HSD17B3, AKR1C3 and SRD5A1 $(n=3)$. (c) Identical treatment in 22RV1 cells showed significant increase in StAR, CYP17A1, HSD3B2 and AKR1C3 mRNA $(n=6)$ and (d) increased 22RV1 proteins CYP11A1, CYP17A1, HSD3B2, AKR1C3 $(n=3)$. Western blots were quantitated using GAPDH loading control (mean + S.E.M.; $* P<0.05)$. are increased intracellularly, while the levels of more potent steroids and androgens increased further down in the pathway were measured in the media. Testosterone and DHT concentrations increased to $44.9 \mathrm{pg} / \mathrm{ml}$ $\left(1.56 \times 10^{-10} \mathrm{~mol} / \mathrm{l}\right)$ and $19.5 \mathrm{pg} / \mathrm{ml}\left(6.74 \times 10^{-11} \mathrm{~mol} / \mathrm{l}\right)$ following IGF2 treatment, once again levels sufficient to activate the AR (Gregory et al. 2001, Titus et al. 2005, Locke et al. 2008). Furthermore, IGF2 treatment was demonstrated to increase DHT secretion in 22RV1 cell medium (Fig. 4c) from 100 to $135 \mathrm{pg} / \mathrm{ml}(P>0.05)$, well within the range necessary for $\mathrm{AR}$ activation. It is possible that IGF2 may activate the AR through mechanisms other than direct activation via steroidogenesis. To address this, our experiments were performed in serum-free medium, assuming that all androgens in the medium capable of inducing AR activation are newly formed. Therefore, it is unlikely that IGF2 activates the receptor in conjunction with the steroids present; our observations are that IGF2 does not enhance steroid activation of PSA.

\section{IGF2 increases induction of AR-regulated genes}

We demonstrated that IGF2-mediated androgen biosynthesis could potentiate AR-mediated gene transcription, using PSA mRNA expression as a surrogate for AR activation in the presence and absence of the AR antagonist bicalutamide. We compared the potency of IGF2 to $10 \mathrm{nM}$ DHT (Fig. 5a). PSA mRNA expression was doubled in LNCaP cells after IGF2 treatment $(P<0.05)$ and we demonstrated that this PSA response was mediated through AR; the addition of bicalutamide abrogated the IGF2-induced increase in PSA expression. Following this, we titrated PSA mRNA expression following IGF2 treatment with increasing concentrations of DHT (Fig. 5b) and found that the concentration of IGF2 used in our studies is approximately as potent as $1.6 \times 10^{-12} \mathrm{M}$ DHT in PSA induction, which is consistent with our measurement of $6.74 \times 10^{-11} \mathrm{M}$ in media.

\section{IGF2 increases de novo steroidogenesis in LNCaP and VCaP medium}

We measured de novo steroidogenesis by treating LNCaP or $\mathrm{VCaP}$ cells for $72 \mathrm{~h}$ with ${ }^{14} \mathrm{C}$-labelled acetate and subsequent HPLC and radiometric detection was used to measure de novo steroidogenesis. In VCaP cells, a fivefold increase in androstenedione and a threefold increase in androsterone levels were detected after IGF2 treatment (Fig. 6a). It is notable that a threefold increase in a steroid peak with a retention time close to that of progesterone

Published by Bioscientifica Ltd. 

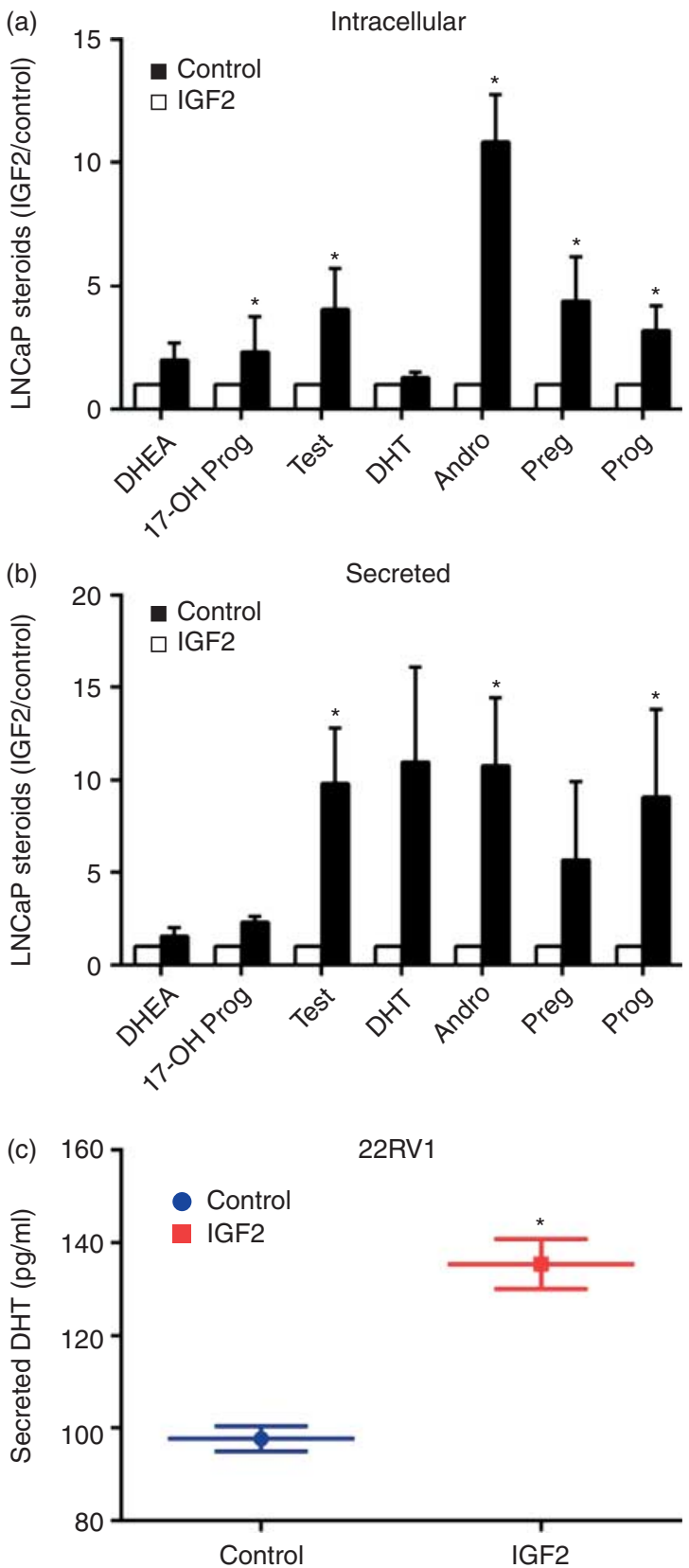

Figure 4

IGF2 treatment increased steroid production in LNCaP cells. LNCaP cells were treated with $85 \mathrm{ng} / \mathrm{ml}$ IGF2 for $48 \mathrm{~h}$. (a) LC-MS used to identify and quantitate intracellular steroids showing a significant increase in $17-\mathrm{OH}$ progesterone (17-OH Prog), testosterone (Test), androsterone (Andro), pregnenolone (Preg) and progesterone (Prog). (b) Extracellular steroids identified and quantitated by LC-MS in media detected significantly increased levels of testosterone (Test), androsterone (Andro) and pregnenolone (Preg) were detected. Steroid levels normalized to cell pellet weight and deuterated testosterone for extraction efficiency and compared to the vehicle time point control $(n=6)$. (c) $22 \mathrm{RV} 1$ cells were treated with $85 \mathrm{ng} / \mathrm{ml}$ IGF2 for $48 \mathrm{~h}$, secreted significantly more DHT compared with vehicle treated $(n=6 ;$ mean + s.E.M.; $* P<0.05)$

(C) 2013 Society for Endocrinology Printed in Great Britain was also detected. We have demonstrated that cold progesterone is present in LC/MS/MS of LNCaP cells in a similar concentration to that of testosterone and androsterone, and this peak proximal to progesterone is also similar in magnitude to those steroids. It is possible that progesterone was compromised in our derivatization procedure. Furthermore, IGF2 treatment in VCaP cells increased pregnan3,20dione, 2.6-fold ( $P<0.05$; Fig. 6a), and de novo cholesterol production, the building block of steroid synthesis (Leon et al. 2010). As the method of extraction used in this experiment is more specific to steroids, the assessment of cholesterol levels should be considered more qualitative than quantitative.

IGF2-treated LNCaP cells significantly increased testosterone, 4.5-fold $(P<0.05)$, as well as androstenedione, androsterone and pregnan-3,17-diol-20-one (approximately fourfold, $P<0.05$; Fig. $6 \mathrm{~b}$ ). In a similar manner to that observed in VCaP cells, there was an increase in the steroid peak resembling progesterone (approximately threefold, $P<0.05)$. IGF2 also induced a 2.4 -fold increase in pregnan-3,20-dione (Fig. 6b). De novo DHT synthesis was not detected in these experiments, as our current methods for steroid extraction of radiolabelled steroids are not effective for extracting DHT.

\section{Receptor blockade of IGF2}

Our IHC analysis of patient TMAs demonstrated increased expression of INSR and IGF1R, which correlated with PC progression; IGF2 can signal through both these receptors or through hybrid INSR:IGF1R. In order to address the relative contribution of each receptor to IGF2-induced steroidogenesis, inhibitors of the insulin signalling axis, including the BMS-754807 tyrosine kinase inhibitor (Carboni et al. 2009, Huang et al. 2010) and the highly specific IGF1R neutralizing antibody, CP-751,871 (Cohen et al. 2005), were used and their effects on IGF2induced steroidogenesis were assessed. BMS-754807 inhibits IGF1R and INSR activity with equal affinity (Carboni et al. 2009), whereas CP-751,871 is highly specific at inhibiting IGF1R activation, including hybrid receptors, with no effect on the INSR (Cohen et al. 2005). Optimal concentrations of inhibitors were determined empirically to assess effectiveness in each cell line but were not optimized for comparison of efficacy.

At the concentrations used, IGF2-induced testosterone synthesis was completely abolished with CP-751,871 compared to 50\% reduction with BMS754807 (Fig. 7a). An 50\% decrease in androstenedione, androsterone and pregnan-3,17-diol-20-one was

Published by Bioscientifica Ltd 
(a)

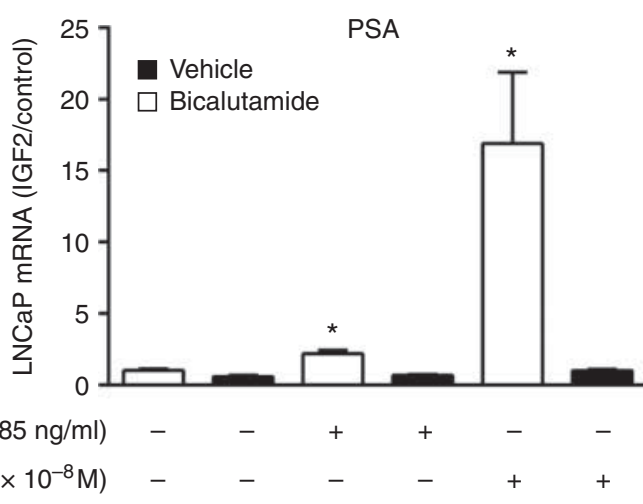

(b)

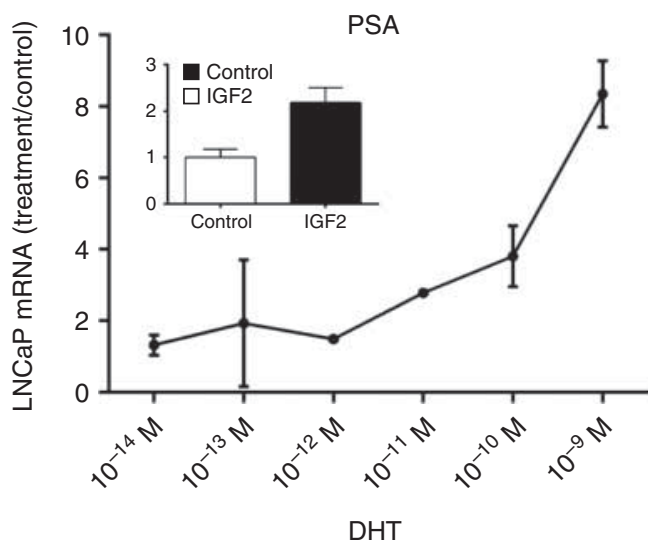

Figure 5

IGF2 increases expression of androgen receptor-regulated genes (a) Increased PSA mRNA following IGF2 treatment was compared to PSA induction by $10 \mathrm{nM}$ DHT. Both IGF2-induced and DHT-induced expression was blocked by AR antagonist bicalutamide. (b) PSA mRNA expression following IGF2 treatment was compared to with increasing concentrations of DHT (0.01 pM-1 nM). DHT induction of PSA mRNA was plotted as a function of concentration. The equation of the line was used to compare IGF2 induction. $85 \mathrm{ng} / \mathrm{ml} \mathrm{IGF2}$ is equipotent to $1.6 \times 10^{-12} \mathrm{M}$ DHT for PSA induction. $\left(n=3\right.$; mean + s.E.M.; $\left.{ }^{*} P<0.05\right)$.

demonstrated with CP-751,871 treatment, with minimal change by BMS-754807 (Fig. 7a). There was little impact by the inhibitors on pregnan-3,20-dione or the steroid peak close to progesterone. QRT-PCR analysis of steroidogenesis enzyme mRNA in LNCaP cells showed that CP-751,871 treatment blocked CYP17A1 expression, which is upstream of androstenedione and may account for the decrease in that key steroid with the IGF1R inhibitor, whereas BMS did not appear to decrease CYP17A1 in LNCaP cells. Both inhibitors decreased levels of StAR, AKR1C3, and HSD17B3 (Fig. 7b). These data suggest that inhibition of the IGF/insulin signalling axis, particularly IGF1R in LNCaPs, reduces IGF2-mediated steroidogenesis.
The same concentrations of inhibitor used in 22RV1 cells completely blocked IGF2-induced DHT secretion with both BMS-754807 and CP-751,871 (Fig. 7c). IGF2induced increases in StAR, CYP17A1 and AKR1C3 protein were equally blocked by both inhibitors (Fig. 7d). Differences in endogenous, basal levels of enzymes, cholesterol and steroid metabolism between the cell lines may explain some of the differences in the relative sensitivity of LNCaPs, VCaPs and 22RV1s to inhibitor treatment (Locke et al. 2009).

We have recently demonstrated that insulin induces steroidogenesis in PC cells (Lubik et al. 2011). We compared the relative potency of $10 \mathrm{nM}$ insulin and $85 \mathrm{ng} / \mathrm{ml}$ IGF2 on PSA mRNA induction in the presence and absence of multiple receptor inhibitors (Fig. 8). Co-treatment with CP-751,871 reduced IGF2-induced PSA expression, as did BMS-754807 (Fig. 8a). Specific inhibition of INSR (and hybrid receptors) with S-661 (Schäffer et al. 2008) had very little effect of induction of PSA by IGF2, suggesting that it signals predominantly through IGF1R over hybrid receptors in this cell line. Ketoconazole, a pan-CYP enzyme inhibitor (Locke et al. 2009), completely abolished PSA induction. By contrast, induction of PSA by insulin was not inhibited by CP-751,871 (Fig. 8b). It was, however, blocked by BMS754804 treatment, as well as S-661, and ketoconazole. In summary, both IGF2 and insulin, albeit with different preferential use of different receptors, induced PSA expression, which was inhibited with the steroidogenesis inhibitor, ketoconazole.

\section{Discussion}

ADT effectively reduces systemic androgens; however, elevated androgen levels persist within PC tumours (So et al. 2005). Previous studies from our group and others indicate that one mechanism driving progression to castrate resistance is the ability of PC cells to initiate a program of de novo steroidogenesis from cholesterol or other precursors, providing androgens to the tumour microenvironment at concentrations sufficient to activate the AR and promote PC growth (Gregory et al. 2001, Locke et al. 2008, 2009, Leon et al. 2010), a process that has rationalized the recent addition of the CYP17A1 inhibitor, abiraterone, to advanced PC therapies. Understanding the mechanisms that regulate intratumoural steroidogenesis in PC is part of ongoing studies in our laboratory aimed at providing new therapies for this stage of disease.

Increased prostatic IGF2 mRNA and protein concentrations have previously been shown to increase during

Published by Bioscientifica Ltd 

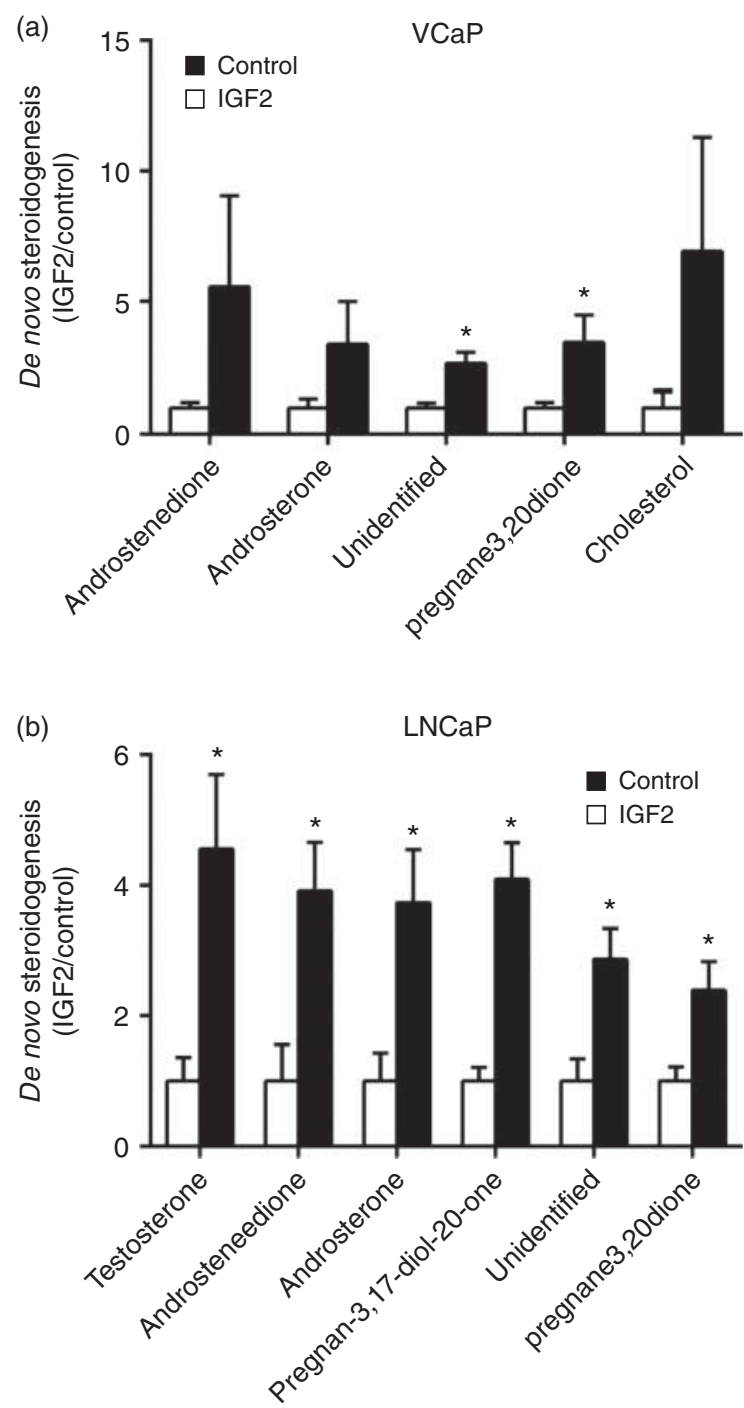

Figure 6

IGF2 increases de novo steroidogenesis in prostate cancer cells. Steroids were extracted from media from VCaP and LNCaP cells after 72-h incubation with $85 \mathrm{ng} / \mathrm{ml} \mathrm{IGF2}$ and $6 \mu \mathrm{Ci} / \mathrm{ml}{ }^{14} \mathrm{C}$-acetate, quantitated by HPLC and radiometric detection. (a) VCaPs responded to IGF2 with increased steroid levels for pregnane3,20dione and a peak close to progesterone in retention time, though trend of increase is evident for androstenedione, androsterone and cholesterol. (b) LNCaPs increased levels of every detected steroid in response to IGF2 treatment (mean + s.E.M. of $n=3 ; * P<0.05$ ).

progression from normal to PIN to PC (Cardillo et al. 2003, Trojan et al. 2006) and correlated with high Gleason scores (Cardillo et al. 2003, Pollak 2008a). In models of androgen deprivation, e.g. LNCaP xenografts in castrated mice, IGF2, IGF1R and INSR mRNA increases significantly from pre-castrate to PSA recurrence (Nickerson et al. 2001, Lubik et al. 2011). Our microarray analysis of clinical samples revealed a steady rise in IGF2 with duration of
NHT, which persisted in CRPC and contrasted with the static expression of IGF2R. Furthermore, studies have shown a correlation between elevated levels of prostatic IGF2 and DHT (Monti et al. 1998). Given the similar signalling pathways between insulin and IGF2, we hypothesized that increased local IGF2 coupled with increased receptors may accelerate local steroid synthesis.

Here, we demonstrate for the first time that IGF2 can promote steroidogenesis in PC cells, LNCaP and 22RV1, via up-regulation of obligatory enzymes (mRNA and protein), coupled with increased total content and de novo synthesis of steroids to concentrations sufficient to activate the AR (Gregory et al. 2001, Locke et al. 2008). IGF2 increased mRNA expression of StAR, CYP17A1, $A K R 1 C 3, S R D 5 A 1$ and RDH5. The importance of increased StAR is a reflection of its key role ferrying cholesterol into the mitochondria for initiation of steroidogenesis. CYP17A1 catalyses several reactions in the pathway including conversion of pregnenolone; both AKR1C3 and HSD17B3 can convert androstenedione to testosterone; and HSD17B3 also contributes to 'backdoor' steroidogenesis through conversion of androsterone to androstanediol (Locke et al. 2008). The 'backdoor' pathway differs from the classical pathway in that it bypasses testosterone in the formation of DHT. SRD5A1 and RDH5 catalyse the final reactions in the synthesis of DHT in the classical and 'backdoor' pathways respectively (Auchus 2004). Once made, DHT is the most potent activator of AR and its pathways and vital to PC survival (So et al. 2005).

The observed differences between LNCaP and 22RV1 cells in IGF2-induced enzyme expression may be explained by their differing origins, LNCaP from lymph node metastasis and 22RV1s from a subclavicular metastasis (Horoszewicz et al. 1980, Sramkoski et al. 1999). The main difference between the two cells lines at $48 \mathrm{~h}$ was the absence of CYP11A1 and HSD3B2 induction in LNCaPs (data not shown) in contrast to significant induction in 22RV1 cells. It is possible that these early enzymes in the steroidogenesis pathway are up-regulated rapidly in LNCaPs in response to IGF2, with levels restored by $48 \mathrm{~h}$. Alternatively, these enzymes may be more active/ abundant in LNCaP cells. Studies have demonstrated that steroidogenic PC cells will bypass inhibition to achieve steroidogenesis depending on cell needs and enzyme availability (Locke et al. 2009).

IGF1 can activate many pathways in PC cells, aside from steroidogenesis, which would contribute to AR-mediated progression. However, in contrast to IGF1, we have observed that IGF2 does not enhance steroid

Published by Bioscientifica Ltd. 
(a)
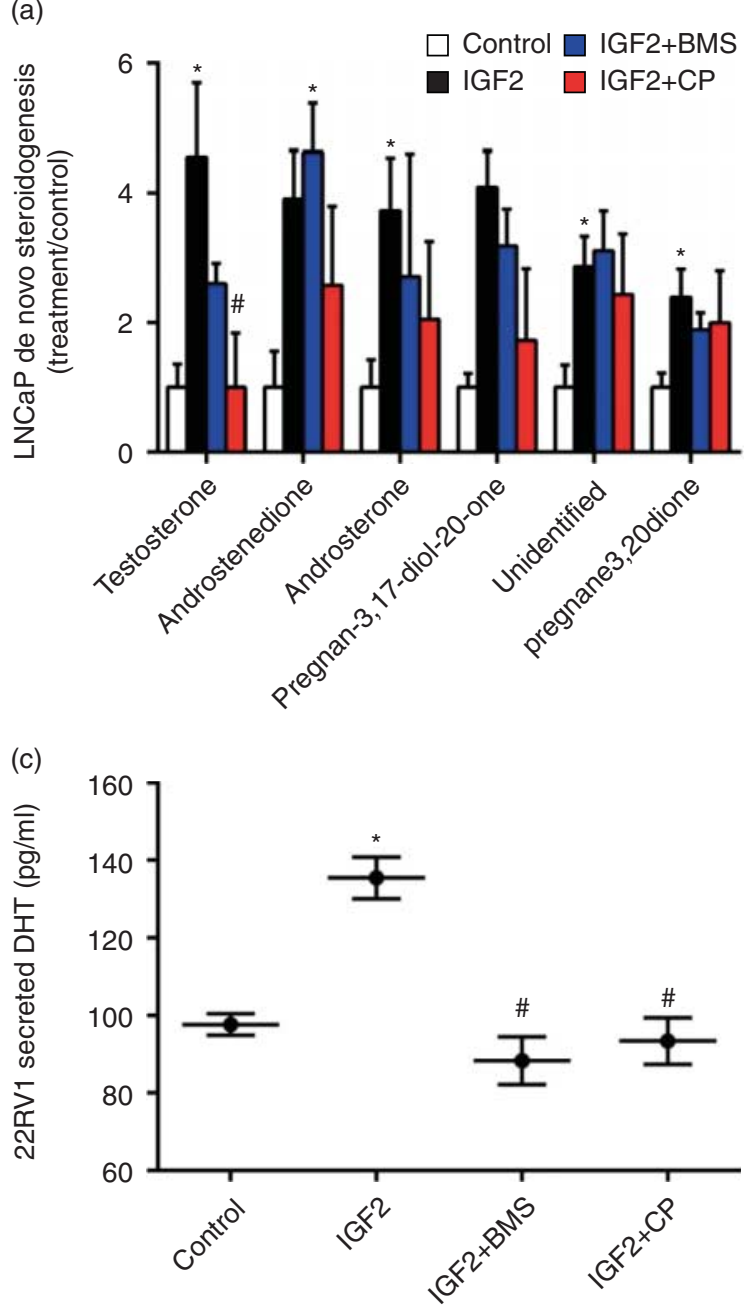

Figure 7

IGF2 increased de novo steroidogenesis in prostate cancer cells, and is blocked by inhibition of IGF1R and hybrid receptors. (a) Medium was collected from LNCaP cells after 72-h incubation with $85 \mathrm{ng} / \mathrm{ml}$ IGF2 and $6 \mu \mathrm{Ci} / \mathrm{ml}^{14} \mathrm{C}$ acetate and in the presence or absence of BMS-754807 pan-INSR and IGF1R inhibitor $(5 \mu \mathrm{M})$ or anti-IGF1R antibody $(12.5 \mu \mathrm{g} / \mathrm{ml})$ CP-751,871. Steroids were quantitated via HPLC/radiometric detection. Steroidogenesis was blocked by CP-751,871 and partially blocked by BMS-754807. (b) Both inhibitors potently inhibited mRNA expression of
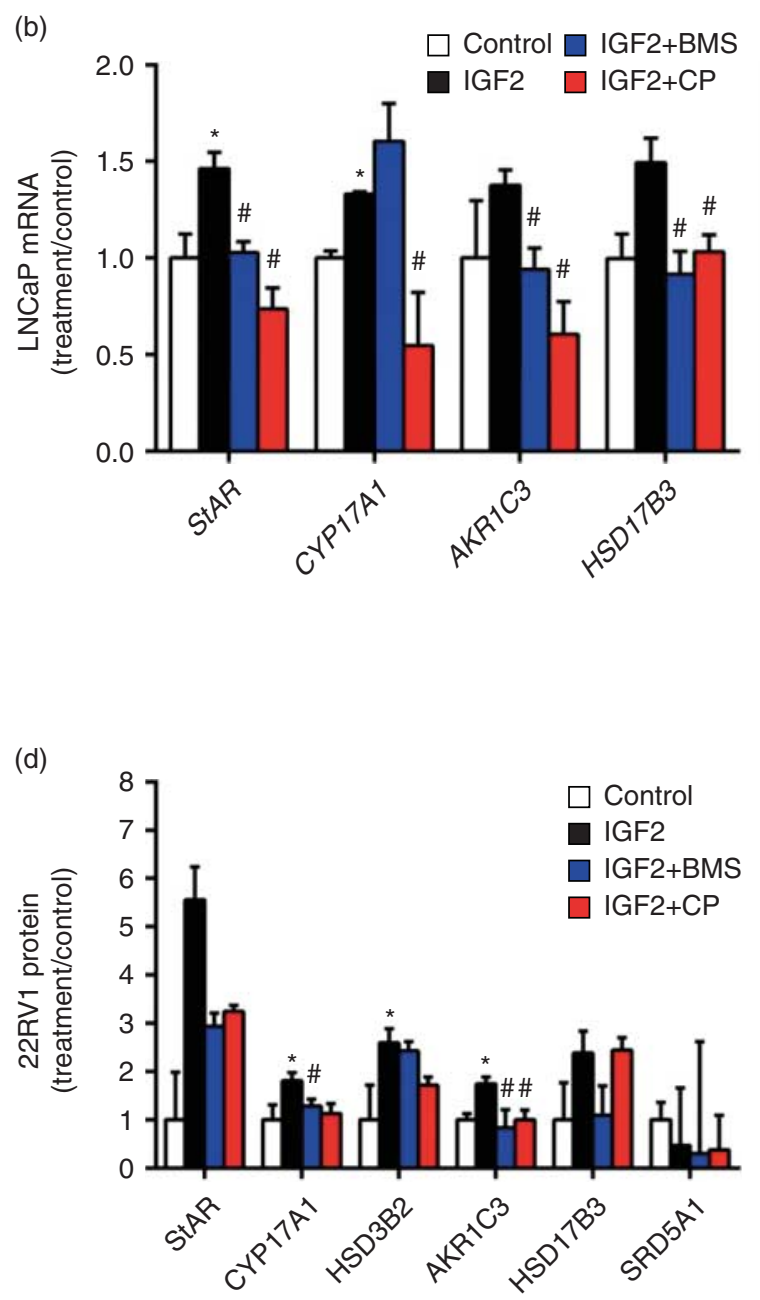

StAR, CYP17A1, AKR1C3 and HSD17B3 in LNCaP cells. (c) Medium from 22RV1 cells following 48-h incubation with IGF2 in the presence or absence of CP-751,871 or BMS-754807 showed inhibition of IGF2-induced steroidogenesis with both inhibitors. (d) Western blot showed that IGF2 increased steroidogenesis enzymes in 22RV1s following IGF2 treatment was blocked by CP-751,8871 or BMS-754807 (mean + S.E.M. of $n=3$; ${ }^{*} P<0.05$ ). ${ }^{\star} P<0.05$ compared to control. ${ }^{\#} P<0.05$ compared to IGF2 treatment.

adrenocortical cells (l'Allemand et al. 1996); however, because IGF2 clearly functions at least in part through IGF1R, it is plausible that IGF1 may also enhance steroidogenesis in PCa cells.

The modulation of both intracellular and extracellular steroid profiles in LNCaP cells by IGF2 compared to our earlier studies with insulin showed considerable differences between the growth factors. In our previous study, $10 \mathrm{nM}$ insulin increased intracellular testosterone levels 60-fold in LNCaPs; here, IGF2 increased testosterone http://erc.endocrinology-journals.org DOI: 10.1530/ERC-12-0250
(C) 2013 Society for Endocrinology Printed in Great Britain 

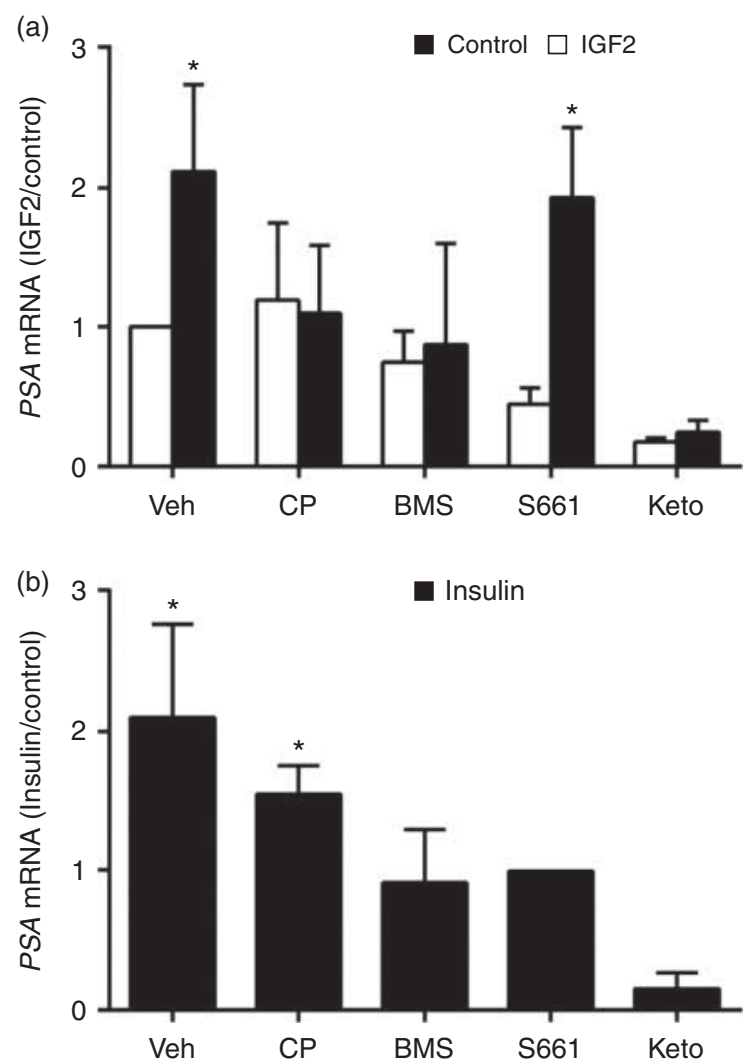

Figure 8

IGF2- and insulin-induced AR activation was blocked by ketoconazole. PSA mRNA expression in LNCaP cells was measured in response to (a) $85 \mathrm{ng} / \mathrm{ml}$ IGF2 treatment and (b) $10 \mathrm{nM}$ insulin in the presence or absence of or

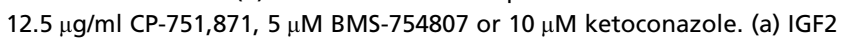
induction of PSA mRNA was blocked in the presence of inhibitors to IGF1R and hybrid receptors, whereas (b) insulin-induced PSA was reduced in the presence of INSR inhibitors (100 nM S661 and BMS-754807. Mean + S.E.M. of $n=3 ; * P<0.05$.

levels fourfold but IGF2 increased secreted DHT and testosterone approximately tenfold, where insulin saw a smaller, twofold increase. In 22RV1 cells, DHT production induced by the two growth factors was similar; insulin increased DHT by 1.7 -fold where IGF2 increased DHT 1.4-fold. BMS-754807, an equipotent inhibitor of INSR and IGF1R, prevented IGF2-induced steroidogenesis in 22RV1s but was less effective in LNCaP cells. One reason for this may be the relative abundance of IGF1R, INSR and hybrid receptors.

The varying amounts of steroidogenesis occurring in our cell lines, in absolute levels, as well as induction, may partially reflect their relative AR mutation status. LNCaP, $\mathrm{VCaP}$ and 22RV1 are androgen responsive; however, each cell line expresses different forms of AR; LNCaP AR harbours the T877A mutation, which renders it promiscuous (Veldscholte et al. 1990), and 22RV1 cells express the less promiscuous AR mutation, $\mathrm{H} 874 \mathrm{Y}$, along with a truncated, constitutively active AR (Tepper et al. 2002), whereas VCaPs express wild-type AR ( Wu et al. 2011). Interestingly, 22RV1s, which have the most cumulative AR mutations, appear to be most steroidogenic in regard to absolute levels of DHT and testosterone synthesis; furthermore, LNCaP cells produce more de novo testosterone and DHT than VCaP cells, which are documented to have the least AR mutations. This supports the concept that steroidogenesis and AR mutations work synergistically to promote PCa (Knudsen \& Penning 2010).

IGF2 signalling can be targeted by pharmacological agents currently in clinical trials (Huang et al. 2010). Inhibition of IGF1R leads to decreased concentrations of steroids downstream of CYP17A1 activity in LNCaP cells, which may indicate that CYP17A1 up-regulation by IGF2 is crucial to steroidogenesis. Further, a decrease in IGF2-induced SRD5A1 would account for the decrease in backdoor pathway steroids, as SRD5A1 may facilitate synthesis through the backdoor pathway, and decreased HSD17B3 and AKR1C3 would result in reduced testosterone (LNCaP) or DHT (22RV1) synthesis in the presence of treatments that target the insulin/IGF receptor signalling axis. Given the temporal changes in IGF2 expression with NHT, IGF2-induced steroidogenesis could also be targeted using CYP17A1 inhibitors, such as abiraterone, which have shown tremendous promise in the clinical setting (Attard et al. 2008, 2011). This is supported by our finding that the pan-CYP inhibitor, ketoconazole, blocked IGF2 activation of AR-mediated PSA expression.

In breast cancer cell lines, it has been shown that blocking either the INSR or the IGF1R can result in increased expression of the other and therefore may not hinder IGF2-related tumour progression (Ulanet et al. 2010). Inhibition of both receptors, or of common downstream effectors, may have therapeutic potential for PC (Sayer et al. 2005). Both CP-751,871 and BMS-754807, which are in clinical trials (Gualberto \& Pollak 2009), demonstrate efficacy in reducing IGF2-induced steroidogenesis and AR activation. IGF2 activates numerous intracellular pathways leading to cancer cell survival, thus combining receptor inhibitors and steroidogenesis inhibitors, such as abiraterone, may also help improve patient outcomes. In summary, IGF2 has been identified as a candidate PC gene target and we provide evidence that IGF2 activates de novo steroidogenesis in PC cell lines.

Published by Bioscientifica Ltd 


\section{Declaration of interest}

The authors declare that there is no conflict of interest that could be perceived as prejudicing the impartiality of the research reported.

\section{Funding}

M P consulted for Pfizer and for Bristol-Myers and received research support from Pfizer. This work was funded by grants from the Queensland Smart Futures Premier's Fellowship, Prostate Cancer Foundation of Australia (PCFA PG25), Terry Fox Program Project (National Cancer Institute of Canada grants 012003 and 017007).

\section{Acknowledgements}

The authors would like to thank Marie-Jose Blouin for excellent technical support.

\section{References}

Attard G, Reid AHM, Yap TA, Raynaud F, Dowsett M, Settatree S, Barrett M, Parker C, Martins V \& Folkerd E 2008 Phase I clinical trial of a selective inhibitor of CYP17, abiraterone acetate, confirms that castrationresistant prostate cancer commonly remains hormone driven. Journal of Clinical Oncology 26 4563. (doi:10.1200/JCO.2007.15.9749)

Attard G, Richards J \& de Bono J 2011 Targeting the androgen receptor signaling pathway in metastatic prostate cancer. Clinical Cancer Research 17 1649-1657. (doi:10.1158/1078-0432.CCR-10-0567)

Auchus R 2004 The backdoor pathway to dihydrotestosterone. Trends in Endocrinology and Metabolism 15 432-438.

Bhusari S, Yang B, Kueck J, Huang W \& Jarrard DF 2011 Insulin-like growth factor-2 (IGF2) loss of imprinting marks a field defect within human prostates containing cancer. Prostate 71 1621-1630. (doi:10.1002/ pros.21379)

Carboni JM, Wittman M, Yang Z, Lee F, Greer A, Hurlburt W, Hillerman S, Cao C, Cantor GH \& Dell-John J 2009 BMS-754807, a small molecule inhibitor of insulin-like growth factor-1R/IR. Molecular Cancer Therapeutics 8 3341. (doi:10.1158/1535-7163.MCT-09-0499)

Cardillo M, Monti S, Di Silverio F, Gentile V, Sciarra F \& Toscano V 2003 Insulin-like growth factor (IGF)-I, IGF-II and IGF type I receptor (IGFR-I) expression in prostatic cancer. Anticancer Research 23 3825-3835.

Chi KN, Eisenhauer E, Fazli L, Jones EC, Goldenberg SL, Powers J, Tu D \& Gleave ME 2005 A phase I pharmacokinetic and pharmacodynamic study of OGX-011, a 2'-methoxyethyl antisense oligonucleotide to clusterin, in patients with localized prostate cancer. Journal of the National Cancer Institute 97 1287-1296.

Cohen BD, Baker DA, Soderstrom C, Tkalcevic G, Rossi AM, Miller PE, Tengowski MW, Wang F, Gualberto A \& Beebe JS 2005 Combination therapy enhances the inhibition of tumor growth with the fully human anti-type 1 insulin-like growth factor receptor monoclonal antibody CP-751,871. Clinical Cancer Research 11 2063. (doi:10.1158/1078-0432. CCR-04-1070)

Cox M, Gleave M, Zakikhani M, Bell R, Piura E, Vickers E, Cunningham M, Larsson O, Fazli L \& Pollak M 2009 Insulin receptor expression by human prostate cancers. Prostate 69 33-40. (doi:10.1002/pros.20852)

Cui H, Cruz-Correa M, Giardiello FM, Hutcheon DF, Kafonek DR, Brandenburg S, Wu Y, He X, Powe NR \& Feinberg AP 2003 Loss of IGF2 imprinting: a potential marker of colorectal cancer risk. Science 299 1753. (doi:10.1126/science.1080902)

Diaz L, Chuan Y, Lewitt M, Fernandez-Perez L, Carrasco-Rodríguez S, Sanchez-Gomez M \& Flores-Morales A 2007 IGF-II regulates metastatic properties of choriocarcinoma cells through the activation of the

http://erc.endocrinology-journals.org DOI: $10.1530 /$ ERC-12-0250 (c) 2013 Society for Endocrinology Printed in Great Britain insulin receptor. Molecular Human Reproduction 13 567-576. (doi:10.1093/molehr/gam039)

Fottner C, Engelhardt D \& Weber M 1998 Regulation of steroidogenesis by insulin-like growth factors (IGFs) in adult human adrenocortical cells: IGF-I and, more potently, IGF-II preferentially enhance androgen biosynthesis through interaction with the IGF-I receptor and IGF-binding proteins. Journal of Endocrinology 158409. (doi:10.1677/joe.0.1580409)

Gregory C, Johnson R, Jr, Mohler J, French F \& Wilson E 2001 Androgen receptor stabilization in recurrent prostate cancer is associated with hypersensitivity to low androgen. Cancer Research $612892-2898$.

Gualberto A \& Pollak M 2009 Emerging role of insulin-like growth factor receptor inhibitors in oncology: early clinical trial results and future directions. Oncogene 28 3009-3021. (doi:10.1038/onc.2009.172)

Harman SM, Metter EJ, Blackman MR, Landis PK \& Carter HB 2000 Serum levels of insulin-like growth factor I (IGF-I), IGF-II, IGF-binding protein-3, and prostate-specific antigen as predictors of clinical prostate cancer. Journal of Clinical Endocrinology and Metabolism 85 4258-4265. (doi:10.1210/jc.85.11.4258)

Horoszewicz J, Leong S, Chu T, Wajsman Z, Friedman M, Papsidero L, Kim U, Chai L, Kakati S, Arya S et al. 1980 The LNCaP cell line - a new model for studies on human prostatic carcinoma. Progress in Clinical and Biological Research 37 115-132.

Huang F, Hurlburt W, Greer A, Reeves KA, Hillerman S, Chang H, Fargnoli J, Graf Finckenstein F, Gottardis MM \& Carboni JM 2010 Differential mechanisms of acquired resistance to insulin-like growth factor-I receptor antibody therapy or to a small-molecule inhibitor, BMS 754807, in a human rhabdomyosarcoma model. Cancer Research 70 7221. (doi:10.1158/0008-5472.CAN-10-0391)

Kalla Singh S, Moretta D, Almaguel F, Wall NR, De Leon M \& De Leon D 2007 Differential effect of proIGF-II and IGF-II on resveratrol induced cell death by regulating survivin cellular localization and mitochondrial depolarization in breast cancer cells. Growth Factors 25 363-372. (doi:10.1080/08977190801886905)

Kim J \& Coetzee GA 2004 Prostate specific antigen gene regulation by androgen receptor. Journal of Cellular Biochemistry 93 233-241. (doi:10.1002/jcb.20228)

Knudsen KE \& Penning TM 2010 Partners in crime: deregulation of AR activity and androgen synthesis in prostate cancer. Trends in Endocrinology and Metabolism 21 315-324. (doi:10.1016/j.tem.2010.01.002)

l'Allemand D, Penhoat A, Lebrethon M, Ardevol R, Baehr V, Oelkers W \& Saez J 1996 Insulin-like growth factors enhance steroidogenic enzyme and corticotropin receptor messenger ribonucleic acid levels and corticotropin steroidogenic responsiveness in cultured human adrenocortical cells. Journal of Clinical Endocrinology and Metabolism 81 3892-3897. (doi:10.1210/jc.81.11.3892)

Leon C, Locke J, Adomat H, Etinger S, Twiddy A, Neumann R, Nelson C, Guns E \& Wasan K 2010 Alterations in cholesterol regulation contribute to the production of intratumoral androgens during progression to castration-resistant prostate cancer in a mouse xenograft model. Prostate 70 390-400. (doi:10.1002/pros.21072)

Livak KJ \& Schmittgen TD 2001 Analysis of relative gene expression data using real-time quantitative PCR and the $2-[\Delta][\Delta]$ CT method. Methods 25 402-408. (doi:10.1006/meth.2001.1262)

Locke JA, Guns ES, Lubik AA, Adomat HH, Hendy SC, Wood CA, Ettinger SL, Gleave ME \& Nelson CC 2008 Androgen levels increase by intratumoral de novo steroidogenesis during progression of castration-resistant prostate cancer. Cancer Research 68 6407. (doi:10.1158/0008-5472.CAN07-5997)

Locke JA, Nelson CC, Adomat HH, Hendy SC, Gleave ME \& Guns EST 2009 Steroidogenesis inhibitors alter but do not eliminate androgen synthesis mechanisms during progression to castration-resistance in LNCaP prostate xenografts. Journal of Steroid Biochemistry and Molecular Biology 115 126-136. (doi:10.1016/j.jsbmb.2009.03.011)

Lubik A, Gunter J, Hendy SC, Locke JA, Adomat H, Thompson V, Gleave M, Pollak M, Herington A \& Nelson C 2011 Insulin directly increases 
de novo steroidogenesis in prostate cancer cells. Cancer Research $\mathbf{7 1}$ 5754-5764. (doi:10.1158/0008-5472.CAN-10-2470)

Monti S, Di Silverio F, Lanzara S, Varasano P, Martini C, Tosti-Croce C \& Sciarra F 1998 Insulin-like growth factor-I and -II in human benign prostatic hyperplasia: relationship with binding proteins 2 and 3 and androgens. Steroids 63 362-366. (doi:10.1016/S0039-128X(98) 00034-8)

Nickerson T, Chang F, Lorimer D, Smeekens SP, Sawyers CL \& Pollak M 2001 In vivo progression of LAPC-9 and LNCaP prostate cancer models to androgen independence is associated with increased expression of insulin-like growth factor I (IGF-I) and IGF-I receptor (IGF-IR). Cancer Research 61 6276-6280.

Pandini G, Conte E, Medico E, Sciacca L, Vigneri R \& Belfiore A 2004 IGF-II binding to insulin receptor isoform A induces a partially different gene expression profile from insulin binding. Annals of the New York Academy of Sciences 1028 450-456. (doi:10.1196/annals.1322.053)

Paradowska A, Fenic I, Konrad L, Sturm K, Wagenlehner F, Weidner W \& Steger K 2009 Aberrant epigenetic modifications in the CTCF binding domain of the IGF2/H19 gene in prostate cancer compared with benign prostate hyperplasia. International Journal of Oncology 35 87-96. (doi:10.3892/ijo_00000316)

Poirier K, Chalas C, Tissier F, Couvert P, Mallet V, Carrié A, Marchio A, Sarli D, Gicquel C \& Chaussade S 2003 Loss of parental specific methylation at the IGF2 locus in human hepatocellular carcinoma. Journal of Pathology 201 473-479. (doi:10.1002/path.1477)

Pollak M 2008a Insulin, insulin-like growth factors and neoplasia. Best Practice \& Research. Clinical Endocrinology \& Metabolism 22 625-638. (doi:10.1016/j.beem.2008.08.004)

Pollak M 2008 $b$ Targeting insulin and insulin-like growth factor signalling in oncology. Current Opinion in Pharmacology 8 384-392. (doi:10.1016/ j.coph.2008.07.004)

Rowlands M, Gunnell D, Harris R, Vatten L, Holly J \& Martin R 2009 Circulating insulin-like growth factor peptides and prostate cancer risk: a systematic review and meta-analysis. International Journal of Cancer 124 2416-2429. (doi:10.1002/ijc.24202)

Rowlands MA, Holly JM, Hamdy F, Phillips J, Goodwin L, Marsden G, Gunnell D, Donovan J, Neal DE \& Martin RM 2012 Serum insulin-like growth factors and mortality in localised and advanced clinically detected prostate cancer. Cancer Causes \& Control 23 347-354. (doi:10.1007/s10552-011-9883-8)

Sayer RA, Lancaster JM, Pittman J, Gray J, Whitaker R, Marks JR \& Berchuck A 2005 High insulin-like growth factor-2 (IGF-2) gene expression is an independent predictor of poor survival for patients with advanced stage serous epithelial ovarian cancer. Gynecologic Oncology 96 355-361. (doi:10.1016/j.ygyno.2004.10.012)

Schäffer L, Brand CL, Hansen BF, Ribel U, Shaw AC, Slaaby R \& Sturis J 2008 A novel high-affinity peptide antagonist to the insulin receptor. Biochemical and Biophysical Research Communications 376 380-383. (doi:10.1016/j.bbrc.2008.08.151)
So A, Gleave M, Hurtado-Col A \& Nelson C 2005 Mechanisms of the development of androgen independence in prostate cancer. World Journal of Urology 23 1-9. (doi:10.1007/s00345-004-0473-1)

Spicer L \& Aad P 2007 Insulin-like growth factor (IGF) 2 stimulates steroidogenesis and mitosis of bovine granulosa cells through the IGF1 receptor: role of follicle-stimulating hormone and IGF2 receptor. Biology of Reproduction 77 18-27. (doi:10.1095/biolreprod.106.058230)

Sramkoski RM, Pretlow TG, Giaconia JM, Pretlow TP, Schwartz S, Sy MS, Marengo SR, Rhim JS, Zhang D \& Jacobberger JW 1999 A new human prostate carcinoma cell line, 22Rv1. In Vitro Cellular \& Developmental Biology 35 403-409. (doi:10.1007/s11626-999-0115-4)

Stanbrough M, Bubley G, Ross K, Golub T, Rubin M, Penning TM, Febbo P $\&$ Balk S 2006 Increased expression of genes converting adrenal androgens to testosterone in androgen-independent prostate cancer. Cancer Research 66 2815-2825. (doi:10.1158/0008-5472.CAN-05-4000)

Tepper CG, Boucher DL, Ryan PE, Ma AH, Xia L, Lee LF, Pretlow TG \& Kung HJ 2002 Characterization of a novel androgen receptor mutation in a relapsed CWR22 prostate cancer xenograft and cell line. Cancer Research 626606.

Titus M, Schell M, Lih F, Tomer K \& Mohler J 2005 Testosterone and dihydrotestosterone tissue levels in recurrent prostate cancer. Clinical Cancer Research 11 4653-4657. (doi:10.1158/1078-0432.CCR-05-0525)

Trojan L, Bode C, Weiss C, Mayer D, Grobholz R, Alken P \& Michel M 2006 IGF-II serum levels increase discrimination between benign prostatic hyperplasia and prostate cancer and improve the predictive value of PSA in clinical staging. European Urology 49 286-292. (doi:10.1016/ j.eururo.2005.08.022)

Ulanet DB, Ludwig DL, Kahn CR \& Hanahan D 2010 Insulin receptor functionally enhances multistage tumor progression and conveys intrinsic resistance to IGF-1R targeted therapy. PNAS $\mathbf{1 0 7} 10791$. (doi:10.1073/pnas.0914076107)

Van Roozendaal C, Gillis A, Klijn J, Van Ooijen B, Claassen C, Eggermont A, Henzen-Logmans S, Oosterhuis J, Foekens J \& Looijenga L 1998 Loss of imprinting of IGF2 and not $\mathrm{H} 19$ in breast cancer, adjacent normal tissue and derived fibroblast cultures. FEBS Letters 437 107-111. (doi:10.1016/S0014-5793(98)01211-3)

Veldscholte J, Ris-Stalpers C, Kuiper G, Jenster G, Berrevoets C, Claassen E, Van Rooij H, Trapman J, Brinkmann A \& Mulder E 1990 A mutation in the ligand binding domain of the androgen receptor of human LNCaP cells affects steroid binding characteristics and response to antiandrogens. Biochemical and Biophysical Research Communications 173 534-540. (doi:10.1016/S0006-291X(05)80067-1)

Wang YC, Yu SQ, Wang XH, Han BM, Zhao FJ, Zhu GH, Hong Y \& Xia SJ 2011 Differences in phenotype and gene expression of prostate stromal cells from patients of varying ages and their influence on tumour formation by prostate epithelial cells. Asian Journal of Andrology $\mathbf{1 3}$ 732-741. (doi:10.1038/aja.2011.11)

Wu Y, Chhipa RR, Zhang H \& Ip C 2011 The antiandrogenic effect of finasteride against a mutant androgen receptor. Cancer Biology \& Therapy 11 902-909. (doi:10.4161/cbt.11.10.15187)

Received in final form 8 December 2012

Accepted 21 December 2012

Made available online as an Accepted Preprint

14 January 2013 http://erc.endocrinology-journals.org

DOI: 10.1530/ERC-12-0250
(C) 2013 Society for Endocrinology Printed in Great Britain
Published by Bioscientifica Ltd. 